\title{
UJI AKTIVITAS ANTIJAMUR INFUSA UMBI BAWANG PUTIH (Allium sativum L.) TERHADAP Candida albicans SERTA PROFIL KROMATOGRAFINYA
}

\section{ANTIFUNGAL ACTIVITY OF INFUSION OF ALLIUM SATIVUM AGAINST Candida albicans AND ITS CHROMATOGRAPHY PROFILE}

\author{
Khusnul Diana ${ }^{1 *}$ \\ ${ }^{1}$ Jurusan Farmasi, Fakultas MIPA, Universitas Tadulako, Palu, Indonesia
}

Received 01 Februari 2016, Accepted 28 Februari 2016

\begin{abstract}
ABSTRAK
Sebagai obat tradisional, umbi bawang putih (Allium sativum L.) berkhasiat sebagai antibakteri dan antijamur selain itu dapat juga berkhasiat sebagai antihipertensi, obat maag, karminativa (pada keadaan dyspepsia), ekspektoransia dan penurun koleserol. Penelitian ini bertujuan untuk menguji aktivitas antijamur infusa umbi bawang putih terhadap Candida albicans serta identifikasi kandungan komponen kimia.Uji aktivitas antijamur dilakukan dengan metode dilusi cair. Parameter yang digunakan pada penentuan aktivitas antijamur yaitu Kadar Hambat Minimum (KHM) dan Kadar Bunuh Minimum (KBM). Konsentrasi yang digunakan adalah $17,5 \% ; 16,25 \% ; 15 \% ; 13,75 \% ; 12,5 \%$; dan $11,25 \% \mathrm{v}$. Uji aktivitas dilakukan dengan menginkubasi infusa ditambahkan pada suspensi jamur dalam media cair CYG DS dan diinkubasi pada suhu $37^{\circ} \mathrm{C}$ selama $18-24$ jam. Identifikasi komponen kimia dilakukan dengan kromatografi kertas dan kromatografi lapis tipis. Hasil penelitian menunjukkan bahwa KHM infusa umbi bawang putih terhadap Candida albicans tidak bisa diamati sebab larutan sudah keruh. Hasil KBM terhadap Candida albicans adalah $15 \%$ \%/v. Hasil uji tabung dan kromatografi menunjukkan bahwa infusa umbi bawang putih mengandung flavonoid dan saponin.
\end{abstract}

Kata kunci: umbi bawang putih (Allium sativum L.), antijamur, Candida albicans

\begin{abstract}
As traditional medicine, bawang putih or garlic ( Allium sativum L.) can cure as antibacterial and antifungal beside on can restorative as antihypertension, antacid, carminativa (in the dyspepsia), expectorancia and anticolesterol. This research was conducted in order to know the antifungal activity of infusion of Allium sativum against Candida albicans and to identify chemical component's of this infusion. The antifungal activity was done by liquid dilution method. The MIC (Minimal Inhibitory Concentration) and MFC (Minimal Fungicidal Concentration) value were used as parameter to determine the antifungal activity. Concentration used in this reseach were $17,5 \% ; 16,25 \% ; 15 \% ; 13,75 \% ; 12,5 \%$ dan $11,25 \% \mathrm{v} / \mathrm{v}$ for Candida albicans. The activity was done by incubating the infusion with fungal in CYG DS media of $37^{\circ} \mathrm{C}$ for $18-24$ hours. Identification of chemical component was carried out by paper chromatography and thin layer chromatography. The result showed that the MIC (Minimum Inhibitor Concentration) for Candida albicans could not be observed because the mixture was turbid. The MFC (Minimum Fungicidal Concentration) for Candida albicans was $15 \% \mathrm{v} / \mathrm{v}$. The tube test and chromatogram showed that the infusion of Allium sativum contained flavonoid, and saponin.
\end{abstract}

Key word: Allium sativum L., Antifungal, Candida albicans.

*Coresponding Author : Khusnul Diana khusnul_diana@yahoo.com (ph : +62-821-5568-0815) 


\section{PENDAHULUAN}

Indonesia adalah negara yang beriklim tropis. Dengan iklim dan keadaan yang seperti ini, tidak mengherankan bila sebagian besar masyarakat Indonesia pernah mengalami infeksi jamur pada kulit. Banyaknya penyakit jamur di daerah tropis antara lain disebabkan oleh faktor keringat dan kebersihan pribadi yang kurang terjaga. Kebanyakan masyarakat mengabaikan pengobatan penyakit ini, padahal bila dibiarkan, akan sangat mengganggu penampilan dan fungsi hidup orang sehari-hari (Dewi, 2004).

Di alam telah ditemukan ribuan jenis jamur, namun hanya 100-200 jenis jamur yang dapat menimbulkan penyakit pada manusia. Dari jumlah ini sebagian dapat menyerang organ dalam sehingga menimbulkan penyakit serius, jamur yang kontak dengan kulit manusia dapat menyebabkan penyakit kulit bahkan ada sebagian jamur yang dapat menghasilkan metabolit beracun (Jawetz et al.,1995).

Jamur merupakan organisme yang bersifat eukaryotik, biasanya dibagi dalam ragi, kapang dan jamur. Metabolismenya bersifat heterotrofik dan absortif, mengadakan reproduksi secara khas melalui mekanisme kawin (seksual) dan tak kawin (aseksual) (Johnson et al, 2001). Infeksi jamur (mikosis) bisa kutan, subkutan, superfisial dan sistemik. Infeksi sistemik paling banyak terjadi pada pasien immunocompromised (pasien AIDS, kortikosteroid, obat-obat antikanker).

C. albicans tampak sebagai sel lonjong, bertunas, Gram positif, berukuran 2-3 X 4,6 $\mu \mathrm{m}$, yang menghasilkan pseudomiselium baik dalam biakan maupun dalam jaringan dan eksudat. Pada agar sabouroud yang dieramkan pada suhu kamar, berbentuk koloni-koloni lunak berwarna coklat yang menyerupai bau seperti ragi. Candida albicans adalah anggota flora normal selaput mukosa saluran pernafasan, saluran pencernaan dan genital wanita. C. albicans dapat menyebabkan penyakit sistemik progresif jika kekebalan tubuh terganggu. C.albicans lebih sering terjadi pada spesies Candida lain dalam menyebabkan infeksi yang simtomatik (Jawetz, et al., 1995).

Candida albicans dapat diatasi dengan menggunakan bahan alam, salah satunya adalah bawang putih. Bawang putih (Allium sativum L.) biasanya digunakan sebagai campuran dalam pengolahan masakan, tapi disamping itu dapat juga digunakan untuk pengobatan tradisional yang memiliki beragam khasiat seperti antimikroba, antikolesterol (menurunkan kadar kolesterol darah), antihipertensi (penurun tekanan darah) dan imunomodulator (meningkatkan sistem kekebalan tubuh) (Hardianto, 2005). Umbi lapis Allium sativum L. mengandung saponin, flavonoid, polifenol dan minyak atsiri (Anonim, 2000).

Flavonoid bersifat merusak membran sel sehingga terjadi perubahan permeabilitas sel yang mengakibatkan terhambatnya pertumbuhan sel atau matinya sel dan polifenol dapat mendenaturasi protein sel jamur. Saponin dapat mengubah tegangan permukaan dengan mengikat lipid yang dapat merusak permeabilitas selektif dari membran sel bakteri (Pelczar dan Chan, 1988).

Senyawa flavonoid dan polifenol merupakan kelompok senyawa fenol yang berfungsi sebagai antijamur sehingga flavonoid dan polifenol dapat digunakan sebagai antijamur (Ganiswarna, 1995). Hal inilah yang mendorong perlunya dilakukan kajian ilmiah yang lebih mendalam mengenai tanaman bawang putih ini terutama bagian umbinya untuk mengetahui aktivitasnya sebagai antijamur.

\section{METODE PENELITIAN \\ Alat dan Bahan}

Alat untuk infundasi : panci infusa, labu takar, timbangan analitik, gelas ukur, kain flannel, corong, kertas saring. Alat untuk uji mikrobiologi : cawan petri, pipet ukur, lampu spritus, mikropipet, tabung reaksi, rak tabung, propipet, ose, yellow tip, blue tip, alat-alat gelas, inkubator, autoclave.

Bahan utama yang digunakan adalah umbi bawang putih yang telah dikeringkan dan dipotong kasar kemudian disari dengan metode infundasi. Bahan untuk pembuatan infusa: umbi bawang putih, aquadest. Bahan untuk uji aktivitas antifungi: Jamur Candida albicans yang merupakan koleksi Laboratorium Fitokimia Universitas Ahmad Dahlan, media jamur yang digunakan adalah media padat (Sabouraud Dextrose Agar) dalam tabung reaksi, bahan lain yang digunakan adalah aquadest steril, $\mathrm{NaCl}$ fisiologis, media CYG DS (Casein Yeast Glucose Double Strength).

\section{Determinasi tanaman}

Untuk mengetahui kebenaran sampel umbi bawang putih yang digunakan maka dilakukan determinasi tanaman di Laboratorium Biologi, 
Fakultas MIPA Universitas Ahmad Dahlan. Hal tersebut dimaksudkan untuk mencocokkan ciri makroskopinya dan ciri morfologinya terhadap pustaka yang ada.

\section{Penyiapan dan pembuatan simplisia}

Umbi bawang putih dicuci dengan menggunakan air mengalir sampai bersih. Kemudian dipotong-potong tidak terlalu tipis lalu dikeringkan di oven pengering kemudian bahan yang sudah kering dipotong kecil-kecil untuk memudahkan penyarian.

\section{Pembuatan infusa}

Diambil simplisia umbi bawang putih sebanyak 10 gram kemudian dimasukan kedalam panci infundasi dan diisi aquadest sampai $100 \mathrm{ml}$, tambahkan air ekstra sebanyak 2 kali berat bahan yaitu 20ml. Campuran ini dipanaskan diatas penangas air selama 15 menit dihitung dari suhu $90^{\circ} \mathrm{C}$ sambil sesekali diaduk. Campuran ini diserkai selagi panas, saring melalui kain flannel kemudian ditambahkan air panas secukupnya melalui ampas sampai di dapat volume infusa $100 \mathrm{ml}$. Pemekatan dilakukan untuk mendapatkan stok infusa dengan kadar $100 \% \mathrm{~b} / \mathrm{v}$ dengan cara menguapkan infusa tadi diatas penangas air sampai didapat volume $10 \mathrm{ml}$, dari stok tersebut kemudian diencerkan sesuai dengan seri kadar yang dikehendaki yaitu 35\%;32,5\% ; 30\% ; $27,5 \% ; 25 \%$ dan $22,5 \% \mathrm{v} / \mathrm{v}$.

\section{Skrining fitokimia \\ Uji keberadaan gugus kromofor}

Larutan infusa yang dihasilkan bila berwarna kuning sampai merah menunjukkan adanya senyawa yang mengandung kromofor (flavonoid, antrakinon dan sebagainya) dengan gugus hidrofilik (gula, asam fenolat dan sebagainya). Bila larutan ditambah larutan $\mathrm{KOH}$ (3 tetes), warna larutan akan menjadi intensif.

\section{Uji flavonoid}

Infusa umbi bawang putih diteteskan di atas kertas saring dan kemudian dilewatkan pada uap ammonia timbul warna kuning pada sampel yang diteteskan tadi.

\section{Uji saponin}

Infusa umbi bawang putih (2 gram) kocok kuat-kuat selama 30 detik, apabila timbul buih setinggi kurang lebih $3 \mathrm{~cm}$ menunjukkan adanya saponin, dan ditambah $\mathrm{HCl}$ encer buih tetap stabil.

\section{Uji Mikrobiologi \\ Penyiapan media}

Media cair CYG DS didapat dari laboratorium Mikrobiologi Fakultas Kedokteran UGM dan media padat SDA didapat dari laboratorium Mikrobiologi Fakultas Farmasi UAD.

\section{Sterilisasi alat-alat}

Semua peralatan yang akan digunakan, seperti cawan petri, pipet ukur, blue tip, yellow tip, tabung reaksi, dan alat-alat gelas lainnya disterilisasi pemanasan kering dengan udara panas atau oven. Tabung reaksi ditutup menggunakan kapas kemudian dibungkus dengan kertas sebelum dimasukkan dalam oven. Pemanasan dilakukan dengan suhu $180^{\circ}$ $\mathrm{C}$ selama $2 \mathrm{jam}$. Sedangkan media dan aquadest disterilkan dalam autoclave pada suhu $121^{\circ} \mathrm{C}$ pada 2 atm selama 15 menit (Volk dan Wheeler, 1993).

\section{Uji Aktivitas Antijamur \\ Pembuatan larutan uji}

Konsentrasi infusa umbi bawang putih yang digunakan untuk $C$. albicans adalah konsentrasi akhir (setelah penambahan susupensi jamur) yaitu $17,5 \% ; 16,25 \% ; 15 \%$; $13,75 \% ; 12,5 \%$ dan $11,25 \% \mathrm{v} / \mathrm{v}$.

\section{Penentuan KHM}

Jamur C. albicans diambil dari suatu biakan dengan menggunakan ose, sebanyak 1 koloni. Goreskan ose tersebut pada media SDA pada suatu tabung yang kemudian diinkubasi selama $18-24$ jam pada suhu $37^{\circ}$ C. Setelah biakan $C$. albicans tersebut tumbuh, tabung tersebut disimpan dalam almari pendingin (suhu $4^{\circ} \mathrm{C}$ ) sebagai stok.

Diambil 1 ose biakan C. albicans yang berumur satu hari kemudian dimasukkan ke dalam kurang lebih $2 \mathrm{ml}$ garam fisiologis, dikocok homogen dan disamakan dengan standart Mc. Farland, kemudian diencerkan dengan media CYG DS (1:100)

Suspensi jamur $10^{6} \mathrm{CFU} / \mathrm{ml}$ C. albicans diambil $0,5 \mathrm{ml}$ dan dimasukkan ke dalam tiaptiap tabung uji yang berisi $0,5 \mathrm{ml}$ larutan uji dalam berbagai konsentrasi. Kemudian diinkubasi pada suhu $37^{\circ} \mathrm{C}$ selama $18-24$ jam. Diamati kejernihan larutan dibandingkan dengan larutan kontrol, untuk menentukan pada 
konsentrasi berapa infusa umbi bawang putih mulai menghambat pertumbuhan jamur.

\section{Penentuan KBM}

KBM ditentukan dengan menggoreskan larutan hasil uji dilusi cair pada media agar untuk $C$. albicans digunakan media agar SDA. Dengan melihat ada tidaknya pertumbuhan jamur dari goresan pada media yang dibandingkan dengan kontrol maka dapat ditentukan berapa konsentrasi terendah larutan infusa umbi bawang putih yang dapat membunuh jamur.

\section{Analisis Data \\ Uji antijamur}

Kadar hambat minimum ditandai dengan kejernihan pada larutan uji pada media Casein Yeast Glucose Double Strenght. Masingmasing sampel dalam tabung uji digoreskan pada media Sabouraud Dextrose Agar . Kadar bunuh minimum ditandai dengan tidak terjadinya pertumbuhan jamur $C$. albicans pada media dan hasilnya dibandingkan dengan kontrol.

\section{Analisis Kromatografi}

Bercak yang timbul sebelum disemprot dapat dilihat di bawah UV 254 dan $366 \mathrm{~nm}$ warna yang timbul nantinya dapat diamati. Selanjutnya plate disemprot dengan penyemprot yang sesuai. Warna dan Rf bercak dibandingkan dengan literatur.

\section{HASIL DAN PEMBAHASAN}

Tanaman bawang putih yang digunakan dalam penelitian ini dideterminasi di Laboratorium Biologi Fakultas MIPA Universitas Ahmad Dahlan Yogyakarta. Tujuan determinasi adalah untuk mengetahui identitas tanaman dengan jelas, sehingga terhindar dari kesalahan dalam pengambilan sampel.

Tabel 1. Hasil uji aktivitas antijamur infusa umbi bawang putih terhadap C. albicans

\begin{tabular}{|c|c|c|c|c|c|c|c|}
\hline \multirow[t]{3}{*}{ No } & \multirow{3}{*}{$\begin{array}{c}\text { Konsentrasi } \\
\text { Perlakuan } \\
\% \text { v/v }\end{array}$} & \multicolumn{6}{|c|}{ HASIL PENGAMATAN } \\
\hline & & \multicolumn{2}{|c|}{ Replikasi I } & \multicolumn{2}{|c|}{ Replikasi II } & \multicolumn{2}{|c|}{ Replikasi III } \\
\hline & & $\mathrm{K} / \mathrm{J}$ & Koloni & $\mathrm{K} / \mathrm{J}$ & Koloni & $\mathrm{K} / \mathrm{J}$ & Koloni \\
\hline 1. & $17,5 \%$ & $\mathrm{~K}$ & - & $\mathrm{K}$ & - & $\mathrm{K}$ & - \\
\hline 2. & $16,25 \%$ & $\mathrm{~K}$ & - & $\mathrm{K}$ & - & $\mathrm{K}$ & - \\
\hline 3. & $15 \%$ & $\mathrm{~K}$ & - & $\mathrm{K}$ & - & $\mathrm{K}$ & - \\
\hline 4. & $13,75 \%$ & $\mathrm{~K}$ & + & $\mathrm{K}$ & + & $\mathrm{K}$ & + \\
\hline 5. & $12,5 \%$ & $\mathrm{~K}$ & + & $\mathrm{K}$ & + & $\mathrm{K}$ & + \\
\hline \multirow[t]{2}{*}{6.} & $11,25 \%$ & $\mathrm{~K}$ & + & $\mathrm{K}$ & + & $\mathrm{K}$ & + \\
\hline & Kontrol & & & & & & \\
\hline 7. & K I & K & - & $\mathrm{K}$ & - & $\mathrm{K}$ & - \\
\hline 8. & K II & $\mathrm{J}$ & - & $\mathbf{J}$ & - & $\mathrm{J}$ & - \\
\hline 9. & K III & $\mathbf{J}$ & - & $\mathbf{J}$ & - & $\mathrm{J}$ & - \\
\hline 10. & K IV & $\mathrm{K}$ & + & $\mathrm{K}$ & + & $\mathrm{K}$ & + \\
\hline
\end{tabular}

Keterangan :

$\mathrm{J}=$ Jernih

$\mathrm{K}=$ Keruh

$+\quad$ = Ada koloni jamur

- $\quad$ = Tidak ada koloni jamur

\section{Kontrol}

K I Kontrol sampel

K II Kontrol media

K III Kontrol pelarut

K IV Kontrol suspensi jamur
$=0,5 \mathrm{ml}$ infusa umbi bawang putih+0,5 $\mathrm{ml} \mathrm{CYG} \mathrm{DS}$

$=1 \mathrm{ml} \mathrm{CYG} \mathrm{DS}$

$=0,5 \mathrm{ml}$ aquadest steril $+0,5 \mathrm{ml} \mathrm{CYG} \mathrm{DS}$

$=0,5 \mathrm{ml}$ suspensi jamur $+0,5 \mathrm{ml} \mathrm{CYG} \mathrm{DS}$ 


\section{Diana et al./Galenika Journal of Pharmacy}
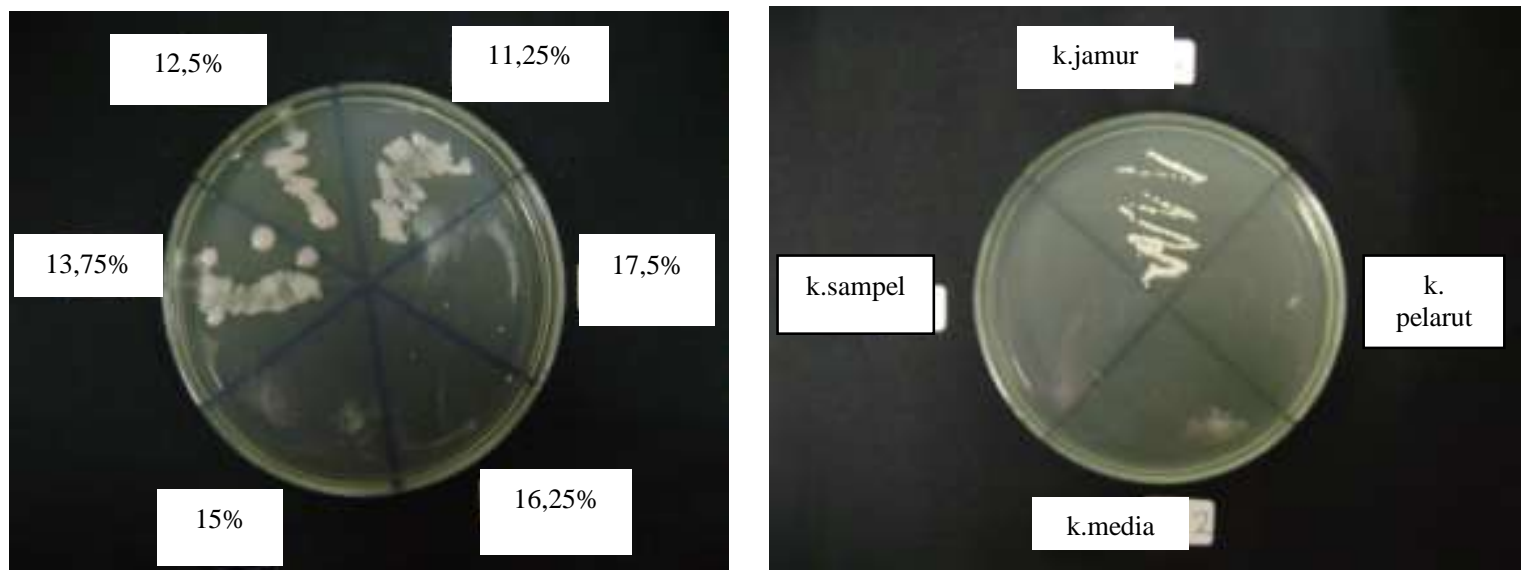

Gambar 1. Hasil uji aktivitas antijamur infusa umbi bawang putih terhadap C. albicans

Tabel 2. Hasil Pemeriksaan Kromatografi Kertas untuk Flavonoid dari Infusa Umbi Bawang Putih

\begin{tabular}{|c|c|c|c|c|c|}
\hline \multirow{2}{*}{ Cuplikan } & $\mathrm{R}_{\mathrm{f}}$ & \multicolumn{3}{|c|}{ Deteksi } & Dugaan \\
\cline { 3 - 5 } & $\mathrm{UV}_{254 \mathrm{~nm}}$ & $\mathrm{UV}_{366 \mathrm{~nm}}$ & Uap amoniak & Flavonoid \\
\hline $\begin{array}{c}\text { Infusa umbi bawang } \\
\text { putih kadar 100\% }\end{array}$ & 0,15 & $\begin{array}{c}\text { Coklat } \\
\text { kekuningan }\end{array}$ & Coklat gelap & Kuning intensif & + \\
\hline Rutin & 0,58 & Kuning & Coklat gelap & Kuning intensif & + \\
\hline
\end{tabular}

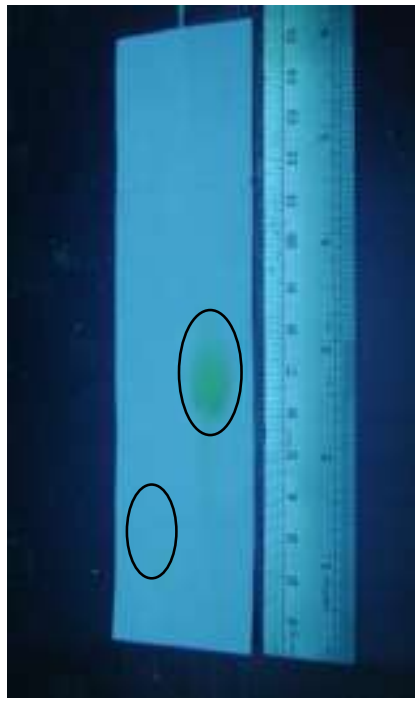

A B

I

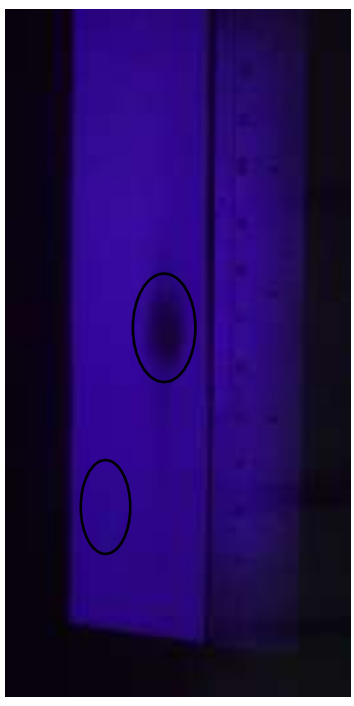

A B

II

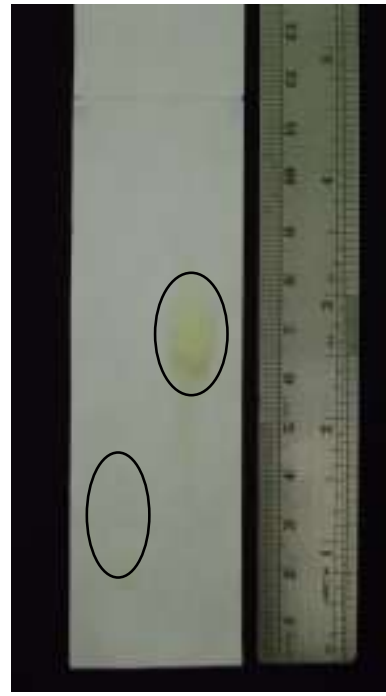

A $\quad$ B

III

Gambar 2. Hasil Pemeriksaan Kromatografi Kertas untuk Flavonoid dari Infusa Umbi Bawang Putih

$\begin{array}{llll}\text { Keterangan : } & \text { Cuplikan : } & \text { A } & \text { : Sampel infusa umbi bawang putih kadar 100\% } \\ & & \text { B } & \text { : Pembanding Rutin } \\ & \text { Deteksi }: & \text { I } & : \text { UV }_{254 n m} \\ & & \text { II } & : \text { UV }_{366 n m} \\ & & \text { III } & \text { Pereaksi semprot uap ammonia }\end{array}$


Penelitian ini menggunakan metode penyarian infundasi karena beberapa kandungan senyawa kimia umbi bawang putih bersifat polar (mudah larut dalam air) sehingga kandungan zat aktif yang larut dalam air tersebut akan tersari dengan baik dan penyarian ini mudah dilakukan oleh masyarakat. Menurut Anonim (1995) kecuali dinyatakan lain dan untuk simplisia yang tidak berkhasiat keras, infusa dibuat menggunakan $10 \% \mathrm{~b} / \mathrm{v}$ simplisia. Infusa yang diperoleh tidak boleh digunakan lebih dari 24 jam karena penyarian menggunakan air akan menghasilkan sari yang mudah tercemar oleh kuman maupun kapang (Anonim, 1995).

Pembuatan infusa dengan menimbang simplisia sebanyak 10 gram dalam aquadest $100 \mathrm{ml}$ ditambah air extra $20 \mathrm{ml}$ yaitu sebanyak $2 \mathrm{X}$ berat bahan, dimaksudkan untuk mencegah kehilangan bahan karena proses penguapan yang terjadi. Infundasi dilakukan menggunakan panci infusa, dipanaskan suhu $90^{\circ} \mathrm{C}$ selama 15 menit, kemudian dipekatkan sampai didapat volume stok $10 \mathrm{ml}$ dengan labu takar. Didapat stok infusa dengan konsentrasi $100 \% \mathrm{~b} / \mathrm{v}$ kemudian diencerkan dengan variasi kadar $35 \%$ ; $32,5 \% ; 30 \% ; 27,5 \% ; 25 \%$ dan $22,5 \% \mathrm{v} / \mathrm{v}$.

Sterilisasi dilakukan pada semua alat dan bahan yang akan digunakan. Tujuannya adalah untuk menghilangkan, mematikan atau menghancurkan semua mikroorganisme hidup, baik yang patogen maupun yang tidak. Untuk alat-alat gelas disterilisasi menggunakan oven dengan suhu $180^{\circ} \mathrm{C}$ selama 2 jam. Media, infusa dan bahan-bahan lain yang akan digunakan disterilisasi dengan autoclave pada suhu $121^{\circ} \mathrm{C}$ selama 15 menit. Hasil sterilisasi dari alat dan bahan yang akan digunakan dapat dilihat dari kontrol yang jernih dan tidak ditumbuhi jamur dan mikroba lain.

\section{Hasil uji aktifitas antijamur infusa umbi bawang putih terhadap C.albicans}

Uji aktifitas antijamur umbi bawang putih terhadap jamur C.albicans ini dilakukan dengan menggunakan sediaan berupa infusa dengan kadar $100 \% \quad \mathrm{~b} / \mathrm{v}$ kemudian dilakukan pengenceran dengan variasi kadar ekstrak $35 \%$ ; $32,5 \% ; 30 \% ; 27,5 \% ; 25 \%$ dan $22,5 \% \mathrm{v} / \mathrm{v}$ menggunakan pelarut aquadest steril.

Penelitian ini menggunakan metode dilusi cair. Dipilih metode dilusi cair karena pada metode ini dapat menghemat media dan bahan uji serta tebal tipisnya media tidak berpengaruh. Selain itu pada metode dilusi cair dapat digunakan untuk menentukan KHM suatu bahan antijamur. Pada dasarnya metode ini dilakukan dengan mengencerkan larutan bahan obat hingga didapat suatu seri kadar dan pada masing-masing kadar obat ditambahkan suspensi jamur ke dalam media cair sehingga memungkinkan berinteraksinya bahan obat yang akan diuji dengan suspensi jamur yang tersebar merata, maka penghambatan terhadap jamur menjadi lebih sensitif.

Variasi konsentrasi ekstrak terdiri dari $35 \%$ ; $32,5 \% ; 30 \% ; 27,5 \% ; 25 \%$ dan $22,5 \% \mathrm{v} / \mathrm{v}$ yang dibuat dari stok $100 \% \mathrm{~b} / \mathrm{v}$, kemudian dilakukan uji aktivitas antijamurnya dengan metode dilusi cair yaitu dengan menambahkan suspensi jamur sebanyak $0,5 \mathrm{ml}$ sehingga dengan perhitungan pengenceran yang dapat dilihat di lampiran 6, didapat konsentrasi akhir $17,5 \% ; 16,25 \% ; 15 \% ; 13,75 \% ; 12,5 \%$ dan $11,25 \% \mathrm{v} / \mathrm{v}$.

Parameter yang digunakan untuk uji aktivitas antijamur adalah KHM yaitu kadar hambat minimum dari infusa umbi bawang putih yang dapat menghambat pertumbuhan jamur. KHM dapat dilihat dari kejernihan yang tampak dari larutan setelah diinkubasi selama 18-24 jam. Pada penelitian nilai KHM tidak dapat diketahui karena larutan yang berwarna keruh dikarenakan didalam infusa umbi bawang putih tersebut terdapat fragmenfragmen yang menyerupai pertumbuhan jamurnya, kemudian dilakukan penggoresan pada media SDA untuk mencari KBM (Kadar Bunuh Minimum) nya. Media agar Sabouraud dextrose agar dipilih karena media tersebut merupakan pembenihan yang mampu menyuburkan pertumbuhan jamur tetapi dapat menghambat pertumbuhan kuman atau bakteri. Dari hasil penggoresan pada media SDA terlihat bahwa pada konsentrasi $13,75 \%$; $12,5 \%$ dan $11,25 \% \mathrm{v} / \mathrm{v}$ ada pertumbuhan jamur sedangkan pada konsentrasi 17,5\% ; 16,25\% dan $15 \% \mathrm{v} / \mathrm{v}$ tidak ada pertumbuhan jamur. Dapat ditarik kesimpulan bahwa KBM yang didapat yaitu pada kadar $15 \% \mathrm{v} / \mathrm{v}$ yaitu kadar terkecil yang dapat membunuh jamur.

Pada penelitian ini dibuat 4 larutan kontrol antara lain kontrol sampel, kontrol media, kontrol pelarut, kontrol suspensi jamur. Larutan kontrol ini memudahkan kita pada saat pengamatan hasil penelitian. Kontrol sampel digunakan untuk melihat kejernihan yang menunjukkan sterilitas sampel yang digunakan yaitu infusa umbi bawang putih ditambah media CYG DS. Kontrol pelarut berfungsi 
sebagai pembanding yang menunjukkan sterilitas pelarut yang digunakan yaitu aquadest ditambah media CYG DS dan untuk mengetahui apakah pelarut yang digunakan memiliki aktivitas antifungi atau tidak. Kontrol media berisi CYG DS tanpa jamur, diperlukan untuk mengetahui sterilitas dari media uji dan tidak boleh ditemukan adanya pertumbuhan jamur. Jika hal itu terjadi maka dapat dipastikan adanya kontaminan pada media tersebut. Kontrol suspensi jamur digunakan untuk memastikan ada tidaknya pertumbuhan mikroba. Data hasil uji aktivitas antijamur infusa umbi bawang putih terhadap C. albicans dapat dilihat pada Tabel I.

\section{Skrining Fitokimia \\ Hasil skrining fitokimia}

Sebelum dilakukan uji kromatografi untuk mengetahui senyawa yang terkandung di dalam umbi bawang putih, terlebih dahulu dilakukan skrining fitokimia. Skrining fitokimia dilakukan untuk mengetahui zat kimia dalam umbi bawang putih (Allium sativum L.) yang kemungkinan berhubungan dengan aktivitas biologi dari sediaan infusa tersebut. Hasil skrining fitokimia diharapkan dapat memberikan gambaran senyawa yang terkandung dalam infusa umbi bawang putih yang berkhasiat sebagai antijamur. Skrining fitokimia dilakukan menggunakan uji tabung, senyawa-senyawa yang diuji meliputi: gugus kromofor, polifenol, tanin, saponin dan flavonoid.

Dari uji tabung diperoleh larutan uji yang berwarna kuning orange dan jika ditambahkan $\mathrm{KOH}$ warna larutan menjadi lebih intensif. Hal ini menunjukkan bahwa umbi bawang putih mengandung gugus kromofor.

Uji saponin dilakukan dengan metode buih yaitu dengan menggojok infusa umbi bawang putih dalam air suling dan dibiarkan lalu diamati tinggi buih yang dihasilkan. Hasil dinyatakan positif bila hasil penggojokan menghasilkan buih kurang lebih $3 \mathrm{~cm}$ dari permukaan dan bersifat stabil setelah ditambah asam. Hasil yang diperoleh untuk uji saponin adalah positif karena setelah ditambahkan asam buihnya tetap stabil.

Uji keberadaan golongan flavonoid dilakukan dengan cara infusa umbi bawang putih diteteskan di atas kertas saring dan kemudian dilewatkan pada uap ammonia timbul warna kuning pada infusa yang diteteskan tadi.
Skrining fitokimia dengan metode tabung yang menghasilkan uji positif dilanjutkan dengan kromatografi sedangkan untuk hasil negatif tidak dilanjutkan uji kromatografi.

\section{Uji kualitatif secara kromatografi}

Uji kualitatif secara kromatografi dilakukan untuk mempertegas uji tabung. Pemeriksaan kandungan kimia dilakukan terhadap senyawa flavonoid dan saponin yang diduga berkhasiat sebagai antijamur.

Kromatografi kertas dapat digunakan untuk memisahkan senyawa flavonoid dalam infusa. Fase gerak yang biasa digunakan adalah n-butanol : asam asetat glasial : air dengan hasil memuaskan karena memberikan bercak yang kompak. Komponen dari BAW (4:1:5) $\% / v$ yang digunakan fase atasnya (Pramono, 1989). Fase diam yang digunakan adalah kertas Whatman no.1 dengan fase gerak n-butanol : asam asetat glasial : air $(4: 1: 5) \mathrm{v} / \mathrm{v}$ fase atas. Cuplikan dibuat dengan konsentrasi $100 \%$ dan ditotolkan sebanyak 3 totolan dengan menggunakan pipa kapiler. Setiap penotolan dilakukan setelah totolan sebelumnya kering. Jumlah penotolan harus optimum, disebabkan karena apabila penotolan terlalu banyak maka penotolan akan terlalu pekat sehingga susah digerakkan oleh cairan pengembang atau fase gerak, sedangkan apabila penotolan terlalu sedikit maka bercak yang dihasilkan samar (Gritter dkk, 1991).

\section{Pemeriksaan Flavonoid}

Senyawa golongan flavonoid dalam infusa umbi bawang putih dielusi dengan menggunakan fase gerak n-butanol : asam asetat glasial : air $(4: 1: 5) \mathrm{v} / \mathrm{v}$ fase atas dan fase diam kertas Whatmann diuapi ammoniak. Menurut Wagner (1984) flavonoid dapat berwarna hitam atau berfluoresensi kuning, orange dan hijau tergantung tipe strukturnya bila dilihat pada UV $366 \mathrm{~nm}$ flavonoid dengan sinar tampak dapat memberikan warna jingga, merah, merah kuning atau merah jambu, coklat tua atau hitam, hijau kuning atau coklat tua dan setelah disemprot sitroborat atau diuapi ammoniak akan berwarna kuning (Harborne, 1996).

Dari kromatografi kertas menunjukkan bahwa infusa umbi bawang putih kemungkinan mengandung senyawa flavonoid. Ini dapat dilihat dari bercak yang mempunyai harga $\mathrm{Rf}$ 0,15. Jika dilihat dengan UV $254 \mathrm{~nm}$ berwarna coklat kekuningan, pada UV $366 \mathrm{~nm}$ coklat 
gelap dan setelah diuapi dengan uap amonia memberikan bercak warna kuning intensif. Hal ini disebabkan dengan penambahan ammonia (basa) akan menyebabkan gugus hidroksil terionisasi, sehingga terjadi pergeseran panjang gelombang yang diserap dan terbentuk warna kuning yang lebih intensif.

Senyawa flavonoid memiliki inti fenol sehingga kemungkinan mekanisme aksi umbi bawang putih dalam membunuh fungi adalah sama dengan mekanisme aksi senyawa fenol pada umumnya yaitu melalui denaturasi dan koagulasi protein sel-sel fungi.

Flavonoid akan membentuk komplek dengan protein membran sel jamur dan pembentukan komplek tersebut menyebabkan kebocoran isi sel dan kematian bakteri. Flavonoid juga dapat menyebabkan koagulasi protein, sehingga sel mengalami lisis karena perubahan permeabilitas membran sel jamur (Simbara, 2008).

\section{Pemeriksaan saponin}

Saponin adalah senyawa yang bersifat polar sehingga dimungkinkan dapat larut dalam air. Glikosida saponin jika dideteksi dengan menggunakan pereaksi semprot vanilin asam sulfat atau anisaldehid asam sulfat akan memberikan warna biru sampai biru violet terkadang berupa bercak berwarna merah atau berupa kuning-coklat. Saponin tidak terdeteksi dalam UV $254 \mathrm{~nm}$ dan UV $366 \mathrm{~nm}$ (Wagner, 1984).

Menurut Harborne (1996) adanya senyawa saponin ditunjukkan dengan warna bercak biru, violet biru atau kadang-kadang kekuningan setelah disemprot dengan pereaksi Vanilin-asam sulfat. Pemeriksaan senyawa saponin dalam infusa umbi bawang putih menggunakan fase gerak kloroform : metanol : air dengan perbandingan $(1: 3: 1) \mathrm{v} / \mathrm{v}$. Fase diam yang digunakan adalah silika gel GF dengan jarak perambatan $8 \mathrm{~cm}$. Hasil kromatografi lapis tipis diketahui bahwa infusa umbi bawang putih kemungkinan mengandung senyawa saponin, hal ini dapat dilihat dari adanya 2 bercak yang memiliki harga $\mathrm{Rf}_{1}$ sebesar 0,31 dan $\mathrm{Rf}_{2}$ sebesar 0,84. Pada $\mathrm{UV}_{254} \mathrm{~nm}$ terjadi pemadaman bercak dan pada $\mathrm{UV}_{366} \mathrm{~nm}$ bercak tidak terdeteksi. Setelah disemprot pereaksi vanilin-asam sulfat memperlihatkan bercak berwarna kuning kecokelatan. Dari kromatogram dapat diduga bahwa pemeriksaan saponin dengan menggunakan kromatografi lapis tipis menunjukkan bahwa pada sampel terbukti adanya saponin, hanya saja pada pemeriksaan $\mathrm{UV}_{254 \mathrm{~nm}}$ diduga terdapat senyawa lain yang menumpuk sehingga terjadi pemadaman bercak.

Saponin termasuk senyawa terpen dan diduga memiliki aktivitas antimikroba, dengan mengganggu membran sel pada bagian atau komponen lipofil dari membran mikroba (Robinson, 1995). Seluruh saponin triterpen dan kelompok saponin monodesmosida mempunyai aktivitas menghemolisis darah, sedangkan saponin bis-desmosida tidak (Rahalison et al, 1995).

Hasil dari skrining fitokimia menunjukkan infusa umbi bawang putih mengandung flavonoid dan saponin. Senyawa fenol akan mendenaturasi protein sel dan mengerutkan dinding sel sehingga dapat melisiskan dinding sel jamur. Senyawa fenol juga dapat merusak membran sel sehingga terjadi perubahan permeabilitas sel yang akan mengakibatkan terhambatnya pertumbuhan sel atau matinya sel. Saponin adalah senyawa aktif permukaan yang kuat yang menimbulkan busa jika dikocok dalam air dan pada konsentrasi yang rendah sering menyebabkan hemolisis sel darah merah. Beberapa saponin bekerja sebagai antimikroba (Robinson, 1995).

Dengan berbagai mekanisme penghambatan pertumbuhan jamur oleh flavonoid, dan saponin terhadap Candida albicans maka dapat dikatakan bahwa infusa umbi bawang putih mempunyai aktivitas antijamur, kemungkinan dengan merusak membran sel jamur, mendenatuasi protein sel serta mengganggu permeabilitas membran sel jamur.

\section{DAFTAR PUSTAKA}

Al-Khatib, I.A.M. (2005). Bawang Dalam Pengobatan Islam, Cetakan ketiga, Penerbit Bumi Aksara, Jakarta, hal 6.

Alexopoulus, C.J. (1970). Introductory of Micology, $2^{\text {nd }}$ edition, John Willey Inc, New York, hal 408-411.

Anonim. (1986). Cara Pembuatan Simplisia, Departemen Kesehatan RI, Jakarta, hal 411.

Anonim. (1995). Materia Medika Indonesia, Jilid V, Departemen Kesehatan RI, Jakarta, 236-239. 
Anonim. (1995). Farmakope Indonesia, Edisi IV, Departemen Kesehatan Republik Indonesia, Jakarta.

Anonim. (2000). Inventaris Tanaman Obat Indonesia (I) Jilid 1, Departemen Kesehatan \& Kesejahteraan Sosial RI Badan Penelitian dan Pengembangan Kesehatan, Jakarta, 15-16.

Ansel, H.C. (1989). Pengantar Bentuk Sediaan Farmasi, edisi ke-4, Universitas Indonesia Press, Jakarta, 411-418.

Backer, C.A., \& van den Brink, R.C.B. (1968). Flora of Java, Volume III, NVP, Noordhoff Broningen, The Netherland.

Clayton, C. (1986). Keputihan \& Infeksi Jamur Kandida Lain, Arcan, Jakarta.

Dewi, D.K. (2004). Infeksi Jamur Pada Kulit, Bali Post, 19 Desember 2004.

Edberg, S. C., \& Berger, S.A. (1986), Antibiotik dan Infeksi, Penerjemah dari Candra Sanusi, EGC, Jakarta.

Gandahusada, S. (1992). Parasitologi Kedokteran, Edisi III,Fakulas Kedokteran Universitas Indonesia, UI Press, Jakarta, 315 .

Gritter, R.J., Bobbit, J.M., Schwarting, A.E. (1991). Pengantar Kromatografi, Edisi II, diterjemahkan oleh Kosasih Padmawinata, Penertbit ITB, Bandung.

Harborne. (1996). Metode Fitokimia Penuntun Cara Modern Menganalisis Tumbuhan, Cetakan ke-2, Diterjemahkan oleh Kokasih Padmawinata dan Iwang Soediro, Penerbit ITB Bandung, 5, 102, 104.

Jawetz, E., Melnick. J.L., Adelberg. A. (1995). Mikrobiologi Kedokteran, alih bahasa oleh Nugroho E., Edisi 20, Jakarta,242-243.

Johnson, A.G. et al. (2000). Mikrobiologi dan Imunologi Seri Ringkasan, Binarupa Aksara, Jakarta, 167-183.
Markham, K.R. (1998). Cara Identifikasi Flavonoid, Diterjemahkan oleh Kokasih Padmawinata, Penerbit ITB Bandung.

Marsh, R.W. (1977). Sistemic Fungicides, $2^{\text {nd }}$ Edition, Longman, London, hal 131-133.

Neal, M.J. (2005). At a Glance Farmakologi Medis, Edisi Kelima, Erlangga Medical Series, Jakarta, hal 86-87.

Nurani, L.H. (2008). Diktat Kuliah Farmakognosi, Fakultas Farmasi Universitas Ahmad Dahlan, Yogyakarta.

Pelczar, M.S., \& Chan. (1986). Dasar-Dasar Mikrobiologi, diterjemahkan oleh Ratna Sri Hadiutomodkk, UI-Press, Jakarta, 41, 46-47, 116-118, 202.

Rahalison, L., Hamburger, M. Hostettmann, K, Morod, M., \& Frenk E,A. (1991). Bioautographic Agar Overlay Method for the Detection of Antifungal Coumpound from Higer Plants, Phytochemical Analysis, 2.

Robinson, T. (1991). Kandungan Organik Tumbuhan Tinggi, Edisi VI, Diterjemahkan oleh Kokasih Padmawinata, Penerbit ITB Bandung, 156157.

Roser, D. (2005). Bawang Putih Untuk Kesehatan, Edisi keempat, Alih Bahasa: Dr. Djaja Surya Atmadja, Bumi Aksara, Jakarta.

Sastrohamidjoyo, H. (1991). Kromatografi, Edisi II, Cetakan ke-2,Penerbit Liberty, Yogyakarta.

Sianturi, M.H.R. (2005). Keputihan Suatu Kenyataan Dibalik Suatu Kemelut, Fakultas Kedokteran Universitas Indonesia, 1-4.

Simbara, Ari. (2008). Bahan Kuliah Kimia Medisinal, Fakultas Farmasi Universitas Ahmad Dahlan, Yogyakarta, 20 Februari 2008.

Stahl, E. (1985). Analisis Obat secara Kromatografi dan Mikroskopi, Penerbit ITB Bandung, 3-4, 16-17. 


\section{Diana et al./Galenika Journal of Pharmacy}

Sudarsono, dkk. (1996). Tumbuhan Obat, Pusat Penelitian Obat Tradisional Universitas Gadjah Mada (PPOT-UGM) Yogyakarta, hal 10-19.

Syamsuhidayat, S.S., Hutapea, J. R. (2001). Inventaris Tanaman Obat (I) Jilid 2, Departemen Kesehatan RI Badan Penelitian dan Pengembangan Kesehatan, Departemen Kesehatan RI, Jakarta, 163.

Tyler, L. \& Brandy, L. (1970). Pharmacognosy, $6^{\text {th }}$, Lea and Febiger, Philadelphia, 186.
Voigt, Rudolf. (1986). Buku Pelajaran Teknologi Farmasi, Diterjemahkan oleh Soendani Noerono Soewandhi dan Matilda B. Widianto, edisi V, Penerbit Gadjah Mada Press, Yogyakarta, 564-574.

Volk, W.A, Wheeler, M.F. (1990). Mikrobiologi Dasar, Edisi 5, Jilid II, diterjemahkan oleh Markham, Penerbit Erlangga, Jakarta, 148. 152-153.

Wagner, H., Bladt, S. (1984). Plant Drug Analysis, Springer-Verlag Berlin Heidelberg, Germany, 170, 306. 